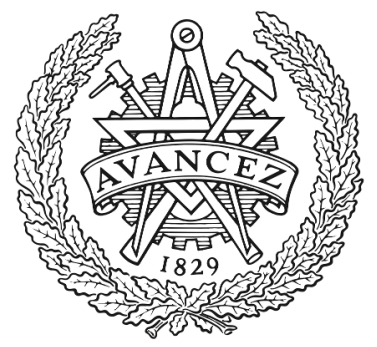

CHALMERS

UNIVERSITY OF TECHNOLOGY

\title{
Sustainability-driven structural design using artificial intelligence
}

Downloaded from: https://research.chalmers.se, 2023-04-26 14:57 UTC

Citation for the original published paper (version of record):

Mathern, A., Ek, K., Rempling, R. (2019). Sustainability-driven structural design using artificial intelligence. 20th Congress of IABSE, New York City 2019: The Evolving Metropolis - Report: 1058-1065

N.B. When citing this work, cite the original published paper. 


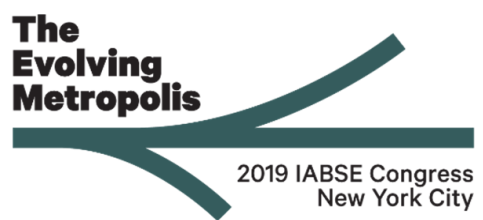

\section{Sustainability-driven structural design using artificial intelligence}

\author{
Alexandre MATHERN \\ $\mathrm{MSc}$ \\ NCC AB / Chalmers Univ. of Tech. \\ Gothenburg, Sweden \\ Structural engineer at $\mathrm{NCC}$ and $\mathrm{PhD}$ \\ student at Chalmers, with interest in \\ advanced design and construction \\ methods in bridge and civil engineering.
}

\author{
Rasmus REMPLING \\ Associate Professor \\ Chalmers University of Technology \\ Gothenburg, Sweden \\ Researcher in the field of Structural and \\ Construction Engineering with interest \\ in AI based and automated processes.
}

Contact: alexandre.mathern@chalmers.se

\section{Abstract}

The construction industry is responsible for a large share of the global environmental impact. The need for addressing sustainability and increased competition calls for the development of innovative design methods that include sustainability in a transparent way. The aim of this work is to propose a framework to use machine learning and artificial intelligence (AI) for structural design optimization based on sustainability and buildability criteria. Al opens up new possibilities to optimize and assess structures early in the planning and design stages. In that way, it is possible to decrease the negative and enhance the positive environmental, economic and social impacts and create a more time- and cost-effective design process. The work is meant to serve as a first step toward the development of Al-based methods in the construction industry, which can bring digitalization in the construction industry to a new level and create new services and business models.

Keywords: Sustainability, structural design optimization, artificial intelligence, set-based design, life cycle sustainability assessment, multi-criteria decision analysis, construction.

\section{Introduction}

The construction industry is often depicted as a conservative industry relying on traditional methods. The European market for the construction industry is growing, and competition as well as the focus on sustainability is increasing. Authorities and municipalities responsible for the transport system and associated infrastructures are today in great need of addressing sustainability when upgrading and renewing the transport system. The same applies to both private and public residential builders. This together with the increased competition calls for an innovative design method that includes sustainability in a transparent way.

Simultaneously, the rapid development of artificial intelligence (AI) can lead to major changes in the structural engineering process and opens up new possibilities to consider sustainability in the design stage. This can help reduce negative and enhance positive environmental, economic and social impacts, lead to a more efficient construction process, cost-effective solutions and new business models. With Al, the construction industry has the possibility to design, evaluate and optimize design concepts faster than ever. With the traditional calculation worksheets and design software used by structural engineers today, such optimization process would be costly and time-consuming.

The purpose of this study is to propose a framework to integrate $\mathrm{Al}$ with structural design and sustainability assessment methods and analyze the potential of this design framework in civil engineering applications. The proposed framework makes it possible to optimize the technical solution 
with regard to sustainability and buildability aspects in an integrated way of working that facilitates collaboration between specialists. It is important to develop these types of cross-disciplinary, integrated ways of working to meet society's sustainability challenges. This requires integrated methods and tools.

This study focuses on the combination of three methods that catalyzes an integrated design approach: set-based design, life cycle sustainability assessment (LCSA) and multi-criteria decision analysis (MCDA); and a framework is proposed to use these methods together with Al.

\section{Background}

This section provides brief descriptions of the different aspects that are forming part of the proposed framework and some of their previous applications in building and civil engineering design.

\subsection{Life cycle sustainability assessment}

Sustainability can be assessed using the Life Cycle Sustainability Assessment (LCSA) model [1]. LCSA is a combined assessment using the tools: life cycle assessment (LCA), life cycle costing (LCC) and social life cycle assessment (SLCA). According to [1], the three separate life cycle assessments shall have consistent, ideally identical, system boundaries and there shall be no weighting between the sustainability domains (option 1 in [1]).

Today it is considered best practice to perform LCA for construction products in accordance with the EN 15804 standard [2]. This standard provides core product category rules (PCR) for all construction products and services. The standard classifies the life cycle stages of a product in modules; modules A1-A3 correspond to the product stage from raw material extraction to building material manufacturing, A4-A5 to the construction process stage, B1-B5 to the use stage relating to maintenance, $B 6-B 7$ to the use stage relating to operation, $\mathrm{C} 1-\mathrm{C} 4$ to the end-of-life stage and module $D$ to the benefits and loads beyond the system boundary. In addition to the EN 15804 standard, there are specific product category rules for bridges, elevated highways and tunnels [3].

LCC for buildings should be performed according to the standards ISO 15686-5 [4] and EN 16627 [5], which include both life cycle costs and incomes. There is not yet an ISO or EN standard on LCC for civil engineering works. The environmental cost of any product or activity can be calculated according to the ISO 14008 standard [6].

SLCA for buildings should be performed according to the standards EN 16309 [7] and EN 15643-3 [8]. The UNEP/SETAC Guidelines for Social Life Cycle Assessment of Products [9] and their Methodological Sheets [10] are also important documents to follow when performing SLCA and choosing social criteria, for any product. There is not yet an ISO or EN standard on SLCA for civil engineering works.

Furthermore, a life cycle sustainability assessment of a bridge can follow the EN 15643-5 standard [11]. This standard outlines a framework on specific principles and requirements for sustainability assessment of civil engineering works. In addition to the modules included in the EN 15804 standard, the EN 15643-5 standard includes the module A0, which is the pre-construction stage, and the module B8, which is the use stage relating to the user's utilization.

\subsection{Buildability}

It can be argued that aspects of buildability are included in the sustainability assessment of an infrastructure's life cycle. This is true with regard to analysis of existing structures, but less practical with regard to early stages of design and tendering activities. In initial stages of design, the risk of the construction engineering activities must be assessed and minimized. Therefore, it is important to give special attention to criteria related to buildability. This buildability awareness in the design stage can lead to seek design solutions that enable ease of construction and to implement platforms for construction products $[12,13]$.

\subsection{Multi-criteria decision analysis}

Multi-criteria decision analysis (MCDA) increases the transparency of the decision process and makes complex decision problems easier to understand. It is a method which takes into account multiple criteria to help decision makers organise information in order to make a confident decision [14]. It is a well-suited method for sustainability 
assessment and has been used for this purpose in many cases in the field of structural engineering [15-18].

MCDA methods applied for sustainable bridge design were reviewed in [15]. The most common methods were identified for each life cycle stage in which they were used. For the design and planning stage and the construction stage, the Analytic Hierarchy Process (AHP) method [19] was most common. For the use stage (maintenance and operation), the AHP in combination with the Fuzzy method was most common, mainly because criteria often were subjective. In the end-of-life stage, the only method used is the Analytic Network Process (ANP).

Questions to help analysts choose a MCDA method adapted to the decision context were formulated in [20]. The crucial question to start with is: what type(s) of results is the method expected to bring?

\subsection{Set-based design}

The traditional structural design process in civil engineering is almost exclusively based on a socalled point-based design approach. In this approach, the development of the design is based on an early choice of a preferred design solution followed by its sequential improvement, which means that many design possibilities are discarded already at an early stage. The ineffectiveness of this approach has motivated the development of alternative design approaches. Toyota was one of the first companies that started using a novel concept, based on parallel and delayed decisionmaking processes called set-based design [21]. In set-based design, the decisions involved in the design process are not made with a single design in mind; instead a set of designs is decided by the stakeholders and progressively narrowed down according to the requirements and choices of those involved in the project.

\subsection{Artificial intelligence}

Artificial Intelligence (Al) and Machine Learning are research areas where the goal is to develop models that can learn to perform predefined assignments, by observing large amounts of data. In recent years, a very rapid development has taken place in these areas, driven primarily by a sharp improvement in computer hardware and by a massive increase in available data.

Al agents can be trained to perform the same tasks as engineers. Human intelligence comes from experience, more iterations of a certain task increase the experience, thereby learning to perform that task with increased precision. Experience can also be achieved by exploring adjacent areas and innovate from the learnings gained.

To train an Al agent for a structural design task, it is important to mimic the procedure that the engineer follows. There are several approaches to how the agent/agents should be organized and one of the most important questions is to decide if the agent should operate on a general or specific level, i.e. should the agent perform the design and propose a solution, or should specific interconnected agents support with specific design tasks, e.g. design the section of a structural member.

The short-term potential with an Al-supported design method is in the increased speed of the design tasks that enables to explore numerous solutions in a minimum time. In the long-term, the potential is in the possibility to include an endless number of criteria.

\section{Proposed framework}

The proposed framework combines parametric design, set-based design and life cycle sustainability assessment coupled with MCDA. The method is further complemented using Al. The method is intended to be used by consultants and contractors in the early stages of a construction project.

\subsection{Set-based parametric design method}

A set-based design approach allows to consider a large number of designs and to evaluate them according to many different criteria in the early design stage. Parameterization is used to allow varying a lot of parameters characterizing the different designs considered. These designs are based on different materials, different material properties for the same type of material, different sectional geometries and sizes, different reinforcement layouts for concrete elements etc. 


\subsection{Multi-criteria life cycle sustainability assessment method}

In the proposed method four main criteria are suggested: the environmental, social and economic dimensions of sustainability, and buildability. The underlying method proposed for the sustainability assessment is option 1 in [1]; LCSA = LCA + LCC + SLCA, with minor alterations, addition of the buildability criterion, and coupled with MCDA. The life cycle sustainability assessment follows the framework outlined in the EN 15643-5 standard. The assessment is performed for the entire life cycle of a bridge; modules $A O$ to $D$ including $B 8$. Each main criterion is decomposed into lower-level criteria that are relevant for the specific project. A comprehensive list of lower-level criteria chosen as important for sustainability assessment of bridges is presented in Table 1. From this list, the most relevant criteria can be chosen for each case to be assessed, based on the site-specific conditions. Each life cycle stage has its own set of lower-level criteria and they are assessed separately for each life cycle stage. Buildability is assessed with lower-level criteria chosen with inspiration from [22], see Table 1. Finally, MCDA is used for the evaluation of designs based on the criteria included, see Figure 1.

\subsection{Integrated framework based on Al}

In the same way as human intelligence, Al uses experience and historical data, which means that $\mathrm{Al}$ has the potential to bring together a breadth of specialists in an integrated approach.

The development of parametric dimensioning that has taken place in recent years has created the conditions for starting to train intelligent algorithms. In the proposed framework, parameterized models are used in a set-based design approach, as developed in [24], to generate and analyze numerous design options, see Figure 1. This parametric set-based design method combines advanced parametric structural design with sustainability assessment and MCDA to evaluate the technical solutions' buildability and sustainability impact. This allows to study the influence of the various parameters. Inferior designs that do not fulfill the design requirements are filtered using several preselected filters (e.g. ultimate limit state (ULS) and serviceability limit state (SLS) checks according to Eurocodes [23]). The
Table 1. Main criteria and lower-level criteria (specific life cycle stages indicated in brackets when applicable).

\begin{tabular}{|c|c|}
\hline Environmental & Social \\
\hline Biodiversity impact & $\begin{array}{l}\text { Safety of construction site } \\
\text { workers }\end{array}$ \\
\hline Water management & $\begin{array}{l}\text { Safety/ security/ resilience } \\
\text { of area of influence }\end{array}$ \\
\hline $\begin{array}{l}\text { Abiotic depletion } \\
\text { potential-minerals \& } \\
\text { metals }\end{array}$ & Stakeholder participation \\
\hline $\begin{array}{l}\text { Abiotic depletion } \\
\text { potential-fossil }\end{array}$ & $\begin{array}{l}\text { Aesthetic perception of } \\
\text { users (only B8) }\end{array}$ \\
\hline Acidification potential & Accessibility/mobility \\
\hline $\begin{array}{l}\text { Global warming potential } \\
\text { (fossil/ biogenic/land use) }\end{array}$ & Time of disturbance \\
\hline Eutrophication potential & $\begin{array}{l}\text { Protection of cultural } \\
\text { heritage }\end{array}$ \\
\hline Soil quality & Noise \\
\hline Waste disposed & Vibration \\
\hline Ozone depletion potential & Job creation \\
\hline $\begin{array}{l}\text { Photochemical ozone } \\
\text { creation potential }\end{array}$ & Equality \\
\hline $\begin{array}{l}\text { Use of primary renewable } \\
\text { energy resources }\end{array}$ & $\begin{array}{l}\text { Water deprivation } \\
\text { potential }\end{array}$ \\
\hline $\begin{array}{l}\text { Use of primary non- } \\
\text { renewable energy } \\
\text { resources }\end{array}$ & Human toxicity potential \\
\hline Components for reuse & $\begin{array}{l}\text { Particulate matter } \\
\text { emissions }\end{array}$ \\
\hline Materials for recycling & Buildability \\
\hline $\begin{array}{l}\text { Materials for energy } \\
\text { recovery }\end{array}$ & Simplicity of design details \\
\hline Exported energy & Material supply reliability \\
\hline Economic & $\begin{array}{l}\text { Technological risks of } \\
\text { methods used }\end{array}$ \\
\hline $\begin{array}{l}\text { Life cycle cost (not B8) } \\
\text { (incl. costs and incomes) }\end{array}$ & $\begin{array}{l}\text { Specific construction work } \\
\text { experience }\end{array}$ \\
\hline Environmental cost & $\begin{array}{l}\text { Repetition on global } \\
\text { structural level }\end{array}$ \\
\hline Users cost (only B8) & $\begin{array}{l}\text { Innovative construction } \\
\text { methods and tools }\end{array}$ \\
\hline
\end{tabular}


remaining options undergo an evaluation routine based on selected LCSA criteria and MCDA methods. This provides a knowledge- and information-based decision-aiding tool for the early stages of a construction project.

Set-based design relies on the generation of a large number of designs that are then iteratively filtered to remove undesirable ones. However, there is no well-defined procedure to generate the initial designs. By adapting and training Al algorithms, suitable designs can be directly suggested without having to conduct the potentially heavy calculations required to find out if a design meets the requirements from building standards or not. Systems using Al can, by observing large amounts of generated designs, draw their own conclusions regarding which additional options are permitted according to building standards and suitable from both a sustainability and a buildability perspective. The Al-based design method will be used as a complement to set-based design method to speed up the process and to be able to provide additional suggestions for options that were not generated in the initial set-based design process. In the final step, a human verification allows to validate the preferred design option.

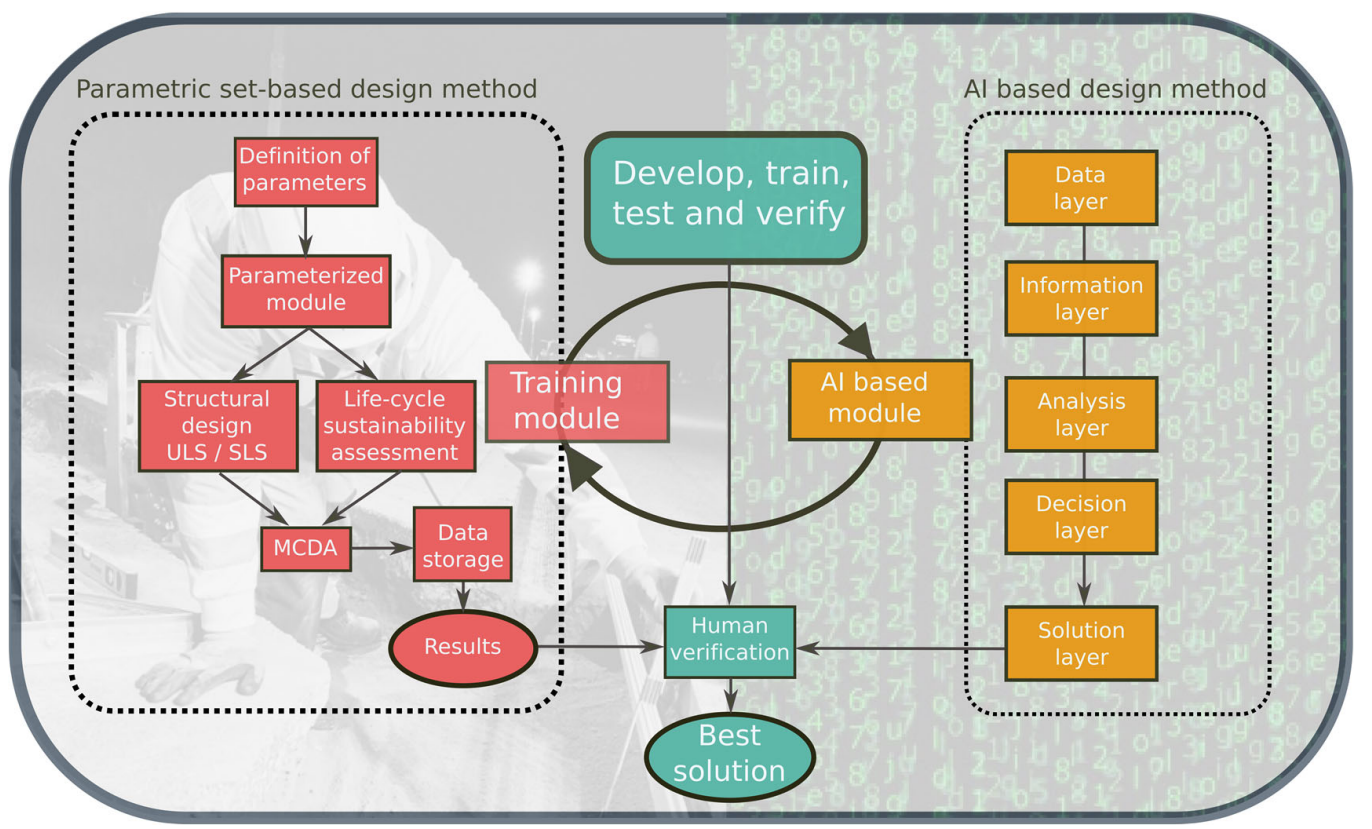

Figure 1. Proposed integrated framework based on Al and the set-based parametric design method developed in [24]. 


\section{Discussion}

The development of Al offers new opportunities to optimize construction projects already at the design stage. In the same way as human intelligence, Al uses experience and historical data. With today's computing power and easily accessible advanced algorithms, the construction industry can gather, evaluate and transfer experience and knowledge regarding the effect of design choices on the entire life cycle of a construction work, see Figure 2 . This is an innovative way of avoiding today's "memory gaps" between projects and sharing knowledge and competence between generations. Great opportunities are opened up to take into account the experiences of previously built structures, from their design, construction and use stages, and to optimize future structures with respect to sustainability criteria.

A SWOT analysis has been conducted to identify the strengths, weaknesses, opportunities and threats of the proposed framework, as presented in Table 2.

The proposed framework does not constitute a solution in itself, but rather a tool for designers to perform repetitive design tasks and achieve better structures. Depending on how it is implemented and used this way of working can either lead to too similar and repetitive solutions or free time for designers to express their creativity. Interrogations that the use of Al may raise on responsibilities are not so critical as long as a traditional complete technical design is required to check the adopted design option.

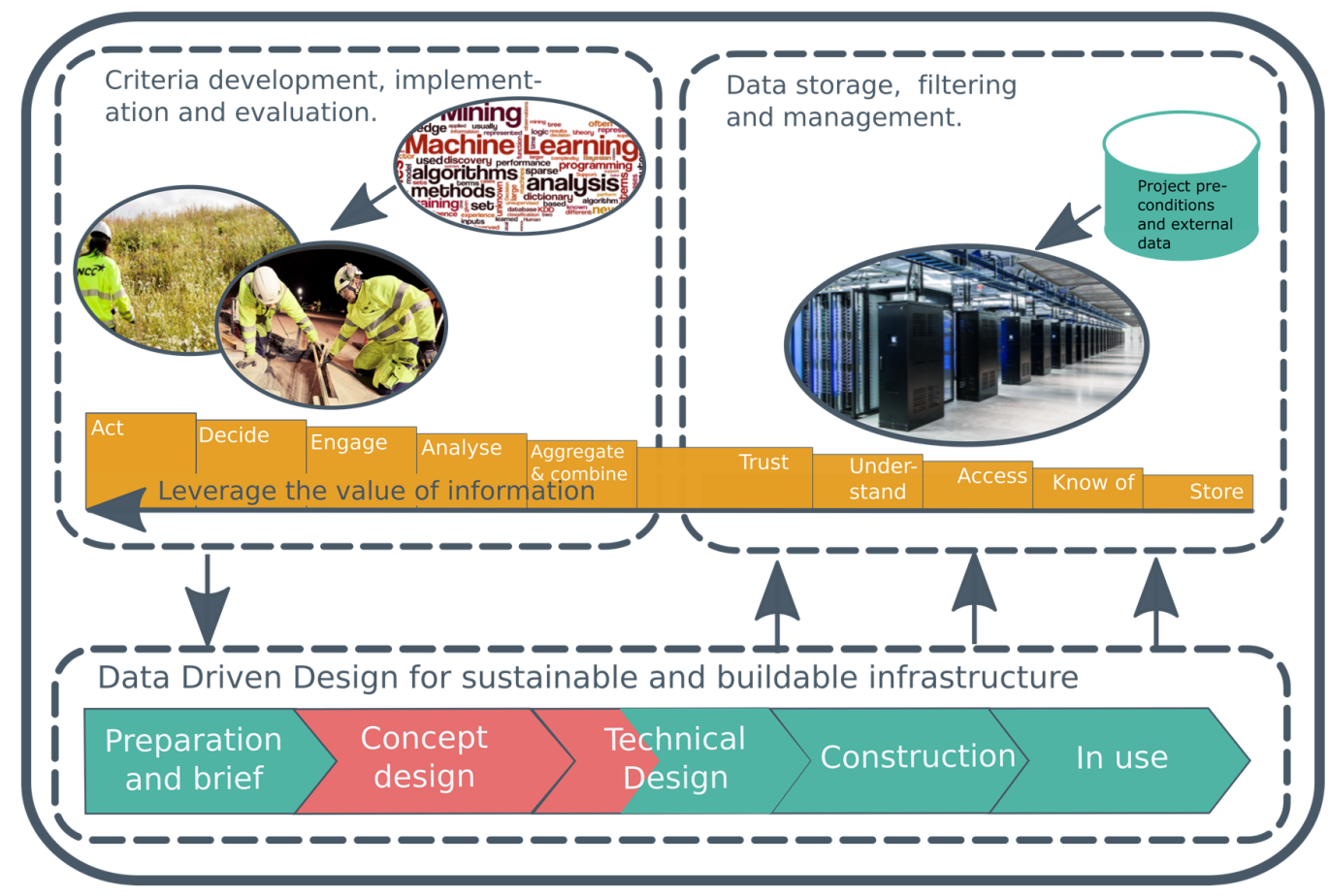

Figure 2. Data-driven design for sustainable and buildable infrastructure. 
Table 2. SWOT analysis of the proposed framework.

\begin{tabular}{|c|c|}
\hline Strengths & Weaknesses \\
\hline $\begin{array}{l}\text { - It allows to consider a large number of designs in } \\
\text { the early design stage. } \\
\text { - The integrated approach based on } \\
\text { parameterization allows to save time in case of } \\
\text { design changes. } \\
\text { - It provides a transparent evaluation and better } \\
\text { understanding of the influence of design choices. } \\
\text { - It offers a good basis for discussion and decisions. } \\
\text { - It enables choosing the most sustainable solution } \\
\text { from a life cycle perspective. }\end{array}$ & $\begin{array}{l}\text { - It requires longer time to be implemented and to } \\
\text { lead to first results. than a "traditional single case } \\
\text { design". } \\
\text { - Considering a larger number of designs requires } \\
\text { longer computing time. } \\
\text { - Through the use of Al, some parts of the process } \\
\text { may become less transparent and control over the } \\
\text { optimization process may be reduced. }\end{array}$ \\
\hline Opportunities & Threats \\
\hline $\begin{array}{l}\text { - The automation of monotonous design tasks can } \\
\text { free time for designers to focus on more creative } \\
\text { activities. } \\
\text { - The use of Al and optimization methods can lead } \\
\text { to substantial reduction of the computing time } \\
\text { required to analyze a large number of designs. } \\
\text { - Proper parameterization and documentation can } \\
\text { facilitate reuse, improvement and extension of } \\
\text { design calculations and models. } \\
\text { - The direct feedback that the designer receives on } \\
\text { his design choices, in terms of sustainability } \\
\text { assessment, facilitates learning and experience } \\
\text { development. } \\
\text { - Using such a framework and gathering } \\
\text { information from existing projects will improve } \\
\text { the trustworthiness of the early sustainability } \\
\text { assessment of designs. } \\
\text { - It can be a catalyst for industrialization of the } \\
\text { design process. }\end{array}$ & $\begin{array}{l}\text { - This way of working may lead to standard and too } \\
\text { uniform structures, which lack human touch. } \\
\text { - A growing complexity of models may affect their } \\
\text { understandability and performance. } \\
\text { - The use of Al raises new questions on the } \\
\text { determination of responsibilities in case of } \\
\text { problems or accidents. } \\
\text { - Intellectual property rights and data ownership } \\
\text { can constitute barriers to collaboration within } \\
\text { projects. } \\
\text { - There is a risk that the criteria evaluation is based } \\
\text { on biased data and unfairly favors certain designs. }\end{array}$ \\
\hline
\end{tabular}

\section{Conclusions}

The rapid development of $\mathrm{Al}$ methods and the growing examples of applications in structural engineering create new possibilities in structural design. The proposed framework, integrating setbased parametric design, multi-criteria life cycle sustainability assessment and Al offers considerable possibilities to train Al algorithms. Al allows to explore the whole set of possible designs to find the most sustainable design while keeping the required computing time low.

\section{Acknowledgments}

This research is funded by the Swedish Transport Administration (Project No. 2017-037), Sweden's innovation agency Vinnova (No. 2017-03312), the strategic innovation programme Smart Built Environment (No. 2018-02630) and NCC AB. The authors would like to thank Christina ClaesonJonsson for her valuable comments on this paper.

\section{References}

[1] Kloepffer W. Life cycle sustainability assessment of products. The International Journal of Life Cycle Assessment 2008; 13: 89-95.

[2] SIS. SS-EN 15804:2012+a1:2013 Sustainability of construction works Environmental product declarations - Core rules for the product category of construction products. 
[3] International EPD System. Product Category Rules - Bridges, elevated highways and tunnels. 2018; Version 1.1.

[4] SIS. ISO 15686-5:2017 - Buildings and constructed assets - Service life planning Part 5: Life-cycle costing. 2017.

[5] SIS. SS-EN 16627:2015 - Sustainability of construction works - Assessment of economic performance of buildings Calculation methods.

[6] SIS. ISO 14008:2019 - Monetary valuation of environmental impacts and related environmental aspects.

[7] SIS. SS-EN 16309:2014+a1:2014 Sustainability of construction works Assessment of social performance of buildings - Calculation methodology. 2014.

[8] SIS. SS-EN 15643-3:2012 - Sustainability of construction works - Assessment of buildings - Part 3: Framework for the assessment of social performance. 2012.

[9] UNEP/SETAC. Guidelines for social life cycle assessment of products. 2009.

[10] UNEP/SETAC. The methodological sheets for sub-categories in social life cycle assessment (S-LCA). 2013.

[11] SIS. SS-EN 15643-5:2017 - Sustainability of construction works - Sustainability assessment of buildings and civil engineering works - Part 5: Framework on specific principles and requirement for civil engineering works.

[12] Simonsson P. Buildability of concrete structures: processes, methods and material. Doctoral thesis, Luleå University of Technology, 2011.

[13] Larsson J. Managing Radical Innovation in the Swedish Infrastructure Sector. Doctoral thesis, Luleå University of Technology, 2016.

[14] Belton V, Stewart TJ. Multiple Criteria Decision Analysis - An integrated approach. Kluwer Academic Publishers, 2002.

[15] Penadés-Plà $V$, García-Segura T, Martí J, et al. A Review of Multi-Criteria DecisionMaking Methods Applied to the Sustainable
Bridge Design. Sustainability 2016; 8: 1295.

[16] Diaz-Balteiro L, González-Pachón J, Romero C. Measuring systems sustainability with multi-criteria methods: A critical review. European Journal of Operational Research 2017; 258: 607-616.

[17] Ek K, Mathern A, Rempling R, et al. Multicriteria decision analysis methods to support sustainable infrastructure construction. In: Proceedings of IABSE Symposium 2019: Towards a Resilient Built Environment - Risk and Asset Management, March 27-29, 2019. Guimarães, Portugal, 2019, p. 8.

[18] Stojčić M, Zavadskas E, Pamučar D, et al. Application of MCDM Methods in Sustainability Engineering: A Literature Review 2008-2018. Symmetry 2019; 11: 350.

[19] Saaty RW. Analytic Hierarchy Process What It Is and How It Is Used. Mathematical Modelling 1987; 9: 161-176.

[20] Roy B, Słowiński R. Questions guiding the choice of a multicriteria decision aiding method. EURO Journal on Decision Processes 2013; 1: 69-97.

[21] Ward AC, Liker JK, Cristiano JJ, et al. The Second Toyota Paradox: How Delaying Decisions Can Make Better Cars Faster. Sloan Management Review, 1995, pp. 4361.

[22] Singhaputtangkul N, Low SP, Teo AL, et al. Criteria for Architects and Engineers to Achieve Sustainability and Buildability in Building Envelope Designs. Journal of Management in Engineering 2014; 30: 236245.

[23] CEN. EN 1990:2002. Eurocode - Basis of structural design. Brussels, 2005.

[24] Mathern A, Rempling R, Tarazona Ramos D, et al. Applying a set-based parametric design method to structural design of bridges. In: International Association for Bridge and Structural Engineering (IABSE) (ed) Proceedings of IABSE Symposium 2018: Tomorrow's Megastructures September 1921, 2018. Nantes, France, p. 8. 